\title{
PENGARUH PENGGUNAAN PUPUK TERHADAP PERTUMBUHAN DAN HASIL PADI SAWAH
}

\author{
Effect of Fertilizer Used on Growth and Yield of Lowland Rice
}

\author{
Misran \\ Balai Pengkajian Teknologi Pertanian (BPTP) Sumatera Barat \\ Jl. Raya Padang-Solok Km 40, Telp. 0755-31564; Fax. 0755-31138 \\ [Diterima Maret 2014, Disetujui Juli 2014]
}

\begin{abstract}
The use of fertilizers with the right amount could increase the growth and yield of lowland rice. This research aims to determine the effect of fertilizer use on the growth and yield of lowland rice. The experiment was conducted on the farmers field in Sungai Lareh, Koto Tangah District, Padang City of West Sumatera Province, from July to December 2009. Research used Randomized Completely Block Design (RCBD) with five replications. The treatments tested were: (A) Urea + $\mathrm{KCl}$, (B) Urea + SP36, (C) Urea + SP36 + KCl, (D) without fertilizers (as control). The dosages of fertilizer were: $150 \mathrm{~kg}$ Urea, $100 \mathrm{~kg} \mathrm{SP} 36$, and $75 \mathrm{~kg} \mathrm{KCl}$ per hectare. The results showed that the use of a complete fertilizer (Urea $+\mathrm{SP} 36+\mathrm{KCl}$ ), or combination of Urea $+\mathrm{KCl}$, or combination of Urea + SP36 had a significant effect on the growth and yield compared to without fertilizer treatment. The use of Urea $+\mathrm{KCl}$ resulted about 5.04 t/ha dry grains harvest $(\mathrm{DGH})$ or increased grain yield as much as $14.03 \%$, and the use of Urea + SP36 gave the results as much as $5.69 \mathrm{t} / \mathrm{ha}$ DGH or increased grain yields as much as $28.73 \%$, and use of a complete fertilizer Urea + SP36 + $\mathrm{KCl}$ gave the results $6.13 \mathrm{t} / \mathrm{ha} \mathrm{DGH}$ or increased yields about $38.69 \%$. Whereas, without fertilized gave only grain yield as much as $4.42 \mathrm{t} / \mathrm{ha} \mathrm{DGH}$.
\end{abstract}

Keywords : lowland rice, specific location, fertilizer, growth, yield.

\begin{abstract}
ABSTRAK
Penggunaan pupuk dengan jumlah yang tepat dapat meningkatkan pertumbuhan dan hasil padi sawah. Pengkajian ini bertujuan untuk mengetahui penggunaan pupuk terhadap pertumbuhan dan hasil padi sawah. Pengkajian dilaksanakan dilahan sawah petani Sungai Lareh Kecamatan Koto Tangah, Kota Padang Propinsi Sumatera Barat, pada bulan Juli sampai Desember 2009. Percobaan menggunakan Rancangan Acak Kelompok (RAK) dengan lima kali ulangan. Perlakuan yang diuji adalah; (A) Urea $+\mathrm{KCl}$, (B) Urea+SP36, (C) Urea $+\mathrm{SP} 36+\mathrm{KCl}$, (D) Tanpa Pupuk (sebagai pembanding). Takaran pupuk yang digunakan adalah $150 \mathrm{~kg}$ Urea, $100 \mathrm{~kg}$ SP36, dan $75 \mathrm{~kg} \mathrm{KCl} / \mathrm{ha}$. Hasil penelitian didapatkan bahwa penggunaan pupuk lengkap (Urea $+\mathrm{SP} 36+\mathrm{KCl}$ ), atau kombinanasi Urea+KCl, atau kombinasi Urea+SP36 menunjukkan pengaruh yang nyata terhadap pertumbuhan dan hasil dibandingkan dengan tanpa pupuk. Penggunaan pupuk Urea+KCl diperoleh hasil 5,04 t/ha gabah kering panen (GKP) atau peningkatan hasil 14,03\%, dan penggunaan pupuk Urea + SP36 diperoleh 5,69 hasil t/ha GKP atau peningkatan hasil 28,73\%, dan penggunaan pupuk lengkap Urea + SP36 + KCl diperoleh hasil 6,13 t/ha GKP atau peningkatan hasil 38,69\%, sedangkan tanpa pupuk hasil yang diperoleh hanya 4,42 t/ha GKP.
\end{abstract}

Kata kunci: Padi sawah, Spesifik lokasi, Pupuk, Pertumbuhan, Hasil.

\section{PENDAHULUAN}

Laju peningkatan produktifitas padi sawah di Indonesia cendrung melandai sehingga diindikasikan bahwa sistem intensifikasi padi sawah yang selama ini diterapkan belum mampu meningkatkan produksi dan produktifitas (Nur, et al. 2003). Pembangunan pertanian tanaman pangan khususnya padi masih tetap terfokus kepada upaya peningkatan produksi yang harus diikuti dengan pengembangan usahatani berbasis agribisnis agar dapat meningkatkan pendapatan petani.

Dalam mewujudkan ketahanan pangan nasional, kendala utama peningkatan produksi 
padi antara lain disebabkan oleh penyusutan luas dan degradasi kesuburan lahan sawah. Rekomendasi pupuk yang bersifat umum, statis, dan tidak efisien di beberapa daerah intensifikasi lahan sawah dimungkinkan adanya ketidak seimbangan hara dalam tanah khususnya diakibatkan oleh phosphat. Menurut Setyorini et. al. (1995), sebagian besar lahan sawah intensifikasi di Jawa, Sumatera Barat, Kalimantan Selatan, Sulawesi Selatan, dan Pulau Lombok sudah tidak respon terhadap pemupukan P dan K.

Umumnya untuk mendapatkan produktifitas yang optimal diperlukan input yang tinggi, sehingga usahatani padi sawah tidak efisien. Hal ini mungkin disebabkan cara pengelolaan lahan yang kurang tepat. Eksploitasi lahan sawah secara intensif, terus menerus dan telah berlangsung bertahun-tahun, mengakibatkan menurunnya kesuburan dan sifat fisik tanah. Intensifnya pemakaian pupuk kimia pada lahan sawah, menyebabkan kandungan bahan organik tanah menurun.

Menurut Adiningsih dan Soepartini (1995) menyatakan bahwa pemberian pupuk anorganik yang berlebihan, menyebabkan kurang tersedianya beberapa unsur hara mikro di dalam tanah, disamping itu tanaman rentan terhadap hama/penyakit sehingga efisiensi pupuk menurun. Kondisi ini menyebabkan turunnya $\mathrm{pH}$ tanah sehingga mikro flora dan fauna mati, tanah menjadi padat, dan tata aerasi menjadi jelek yang akhirnya menghambat perkembangan akar dan pertumbuhan tanaman.

Di Sumatera Barat, sekitar 16,8\% areal persawahan mempunyai kadar P-tanah rendah, 42,5\% berkadar sedang, dan $40,7 \%$ berkadar tinggi (Burbey et. al., 2000). Kondisi ini disebabkan rekomendasi pupuk pada sawah intensifikasi masih bersifat umum sehingga menyebabkan munculnya kecenderungan meningkatkan akumulasi $\mathrm{P}$ dan $\mathrm{K}$ di lahan sawah. Pada hal, rekomendasi pupuk seharusnya bersifat spesifik lokasi, sangat tergantung pada iklim, tanah, dan tanaman (Widjaya Adhi, 1993).

Uji tanah dan tanaman telah lama digunakan sebagai indikator perlu atau tidaknya pemberian pupuk bagi tanaman. Namun cara ini memiliki keterbatasan sehingga sangat kecil kemungkinan petani sebagai pengguna terlibat langsung dalam kegiatan pengujian atau dalam penetapan kebutuhan pupuk. Selain itu, implementasi di lapangan menggunakan data hasil uji tanah dan atau uji tanaman, hasilnya sering kurang memuaskan (Balitpa, 2003).

Fakta dilapangan menunjukkan bahwa pada umumnya petani (di lokasi percobaan) tanaman tidak dipupuk menurut yang semestinya, bahkan ada pendapat bahwa untuk tanaman padi sawah penggunaan Urea adalah sangat penting sedangkan pupuk TSP/SP36 dan $\mathrm{KCl}$ diberikan jika kondisi "memungkinkan". Penelitian ini bertujuan untuk mengetahui pengaruh penggunaan pupuk $\mathrm{P}$ dan $\mathrm{K}$ terhadap pertumbuhan dan hasil padi sawah khususnya di daerah Sungai Lareh dan sekitarnya.

\section{METODE PENELITIAN}

Penelitian dilaksanakan di lahan sawah petani Sungai Lareh Kecamatan Koto Tangah Kota Padang, Propinsi Sumatera Barat dari bulan Juli sampai Desember 2009. Percobaan disusun dalam Rancangan Acak Kelompok (RAK), dengan lima kali ulangan. Perlakuan yang diuji adalah; (A) Urea $+\mathrm{KCl}$, (B) Urea + SP36, (C) Urea + SP36 + KCl, (D) Tanpa pupuk (Kontrol). Takaran pupuk yang digunakan adalah $150 \mathrm{~kg}$ Urea, $100 \mathrm{~kg} \mathrm{SP} 36$, dan $75 \mathrm{~kg} / \mathrm{ha}$ KCl. Pupuk Urea dan $\mathrm{KCl}$ diberikan 3 (tiga) kali secara tebar rata pada 7, 28, dan 55 hari setelah tanam (hst), sedangkan pupuk SP36 diberikan seluruhnya pada 7 hst bersamaan dengan pemberian pupuk Urea dan $\mathrm{KCl}$.

Varietas yang digunakan adalah Cisokan dengan sistem tanam pindah, ditanam 3 batang/rumpun, jarak tanam $25 \times 25 \mathrm{~cm}$, luas plot $5 \times 5$ meter. Pengendalian hama dan penyakit tanaman dilakukan berdasarkan konsep PHT (Pengendalian Hama Terpadu), penyiangan dilakukan dua kali yaitu umur 25 dan 50 hst. Pengamatan dilakukan terhadap tinggi tanaman, jumlah anakan, komponen hasil dan hasil. 
Tabel 1. Pengaruh Penggunaan Pupuk Terhadap Tinggi Tanaman, Jumlah Anakan Maksimum dan Anakan Produktif Padi Sawah, Sungai Lareh Kecamatan Koto Tangah, Kota Padang. 2009.

\begin{tabular}{clccc}
\hline \multirow{2}{*}{ No. } & \multirow{2}{*}{ Perlakuan } & \multirow{2}{*}{ Tinggi tanaman $(\mathrm{cm})$} & \multicolumn{2}{c}{ Rataan anakan (btg/rpn) } \\
\cline { 3 - 5 } & & $109,6 \mathrm{a}$ & Maksimum & Produktif \\
\hline $\mathrm{A}$ & Urea+KCl & $11,7 \mathrm{a}$ & $20,7 \mathrm{c}$ & $13,3 \mathrm{c}$ \\
$\mathrm{B}$ & Urea+SP36 & $109,5 \mathrm{a}$ & $23,5 \mathrm{a}$ & $16,8 \mathrm{~b}$ \\
$\mathrm{C}$ & Urea+SP36+KCl & $101,5 \mathrm{~b}$ & $17,4 \mathrm{c}$ & $13,6 \mathrm{a}$ \\
$\mathrm{D}$ & Tanpa Pupuk (Kontrol) & 8,92 & 15,07 & 6,03 \\
\hline \multicolumn{2}{l}{ KK (\%) } & \multicolumn{2}{c}{ Angka pada lajur yang diikuti oleh huruf yang sama tidak berbeda nyata pada taraf uji DNMRT 5\%. }
\end{tabular}

\section{HASIL DAN PEMBAHASAN}

\section{Pertumbuhan Tanaman}

Hasil penelitian menunjukkan bahwa perlakuan pemupukan berpengaruh nyata terhadap tinggi tanaman, anakan maksimum, dan anakan produktif.

Pada Tabel 1 terlihat bahwa tinggi tanaman tertinggi ditunjukkan pada perlakuan (B) Urea + SP36 $(111,7 \mathrm{~cm})$ tidak berbeda nyata dengan perlakuan (A) Urea $+\mathrm{KCl}(109,6$ $\mathrm{cm})$, dan perlakuan $(\mathrm{C})$ Urea $+\mathrm{SP} 36+\mathrm{KCl}$ $(109,5 \mathrm{~cm})$ akan tetapi berbeda nyata dengan perlakuan (D) tanpa pupuk $(101,5 \mathrm{~cm})$. Hal ini diduga karena hara tanah terutama phospor dan kalium cukup tersedia sehingga tanpa penggunaan phospor saja (perlakuan A) atau tanpa kalium saja (perlakuan B) didapat tinggi tanaman yang relatif sama dengan perlakuan (C). Namun demikian jika pupuk tidak diberikan (perlakuan D), maka tinggi tanaman lebih rendah. Menurut Darwis (1979), tanaman padi kekurangan nitrogen dapat menyebabkan tanaman kurang subur, yang dicirikan dengan rendahnya tinggi tanaman dan jumlah anakan sedikit. Rataan anak maksimum terbanyak didapatkan pada perlakuan (C) Urea + SP36 + $\mathrm{KCl}(23,5 \mathrm{btg} /$ rumpun $)$ dan berbeda nyata dengan semua perlakuan. Perlakuan penggunaan pupuk Urea + SP36 $+\mathrm{KCl}$ memberikan jumlah anakan produktif yang nyata lebih banyak $(18,6$ btg/rumpun) dibandingkan perlakuan lainnya. Rataan anak maksimum yang nyata lebih sedikit dibandingkan dengan perlakuan lainnya didapat pada perlakuan $\mathrm{D}(17,4 \mathrm{btg} / \mathrm{rumpun})$ dan perlakuan A (17,5 btg/rumpun), dan rataan anak produktif yang nyata lebih sedikit juga didapat pada perlakuan A (13,3 btg/rumpun) dan perlakuan D (13,5 btg/rumpun). Menurut Sarief (1985) salah satu peran phospor adalah dalam pembelahan sel, apabila laju pembelahan sel cepat, akan mendorong pertumbuhan anakan dan organ lainnya. Dengan berkurangnya hara phospor aktifitas tersebut menjadi berkurang sehingga anakan yang dihasilkan sedikit.

\section{Komponen Hasil}

Komponen hasil tanaman yang diamati adalah panjang malai, jumlah gabah permalai, jumlah gabah bernas permalai, dan berat 1000 butir. Hasil penelitian menunjukkan bahwa perlakuan penggunaan pupuk phospor dan kalium mempengaruhi secara nyata terhadap semua komponen hasil yang diamati.

Pada Tabel 2 terlihat bahwa panjang malai berkisar $18,3-22,9 \mathrm{~cm}$, dimana malai terpanjang didapat pada perlakuan (C) Urea +

Tabel 2. Pengaruh Penggunaan Pupuk Terhadap Panjang Malai, Jumlah Gabah Per Malai, Jumlah Gabah Bernas Per Malai dan Berat 1000 Biji Padi Sawah Sungai Lareh Kecamatan Koto Tangah Kota Padang Tahun 2009.

\begin{tabular}{clcccc}
\hline No. & Perlakuan & $\begin{array}{c}\text { Panjang } \\
\text { malai }(\mathrm{cm})\end{array}$ & $\begin{array}{c}\text { Jumlah gabah } \\
\text { per malai } \\
\text { (butir) }\end{array}$ & $\begin{array}{c}\text { Jumlah gabah } \\
\text { bernas per malai } \\
\text { (butir) }\end{array}$ & $\begin{array}{c}\text { Berat } 1000 \\
\text { butir } \\
(\text { gram })\end{array}$ \\
\hline A & Urea+KCl & $20,8 \mathrm{~b}$ & $107,30 \mathrm{c}$ & $91,4 \mathrm{~d}$ & $22,9 \mathrm{c}$ \\
B & Urea+SP36 & $22,5 \mathrm{a}$ & $112,75 \mathrm{~b}$ & $98,5 \mathrm{c}$ & $24,5 \mathrm{~b}$ \\
C & Urea+SP36+KCl & $22,9 \mathrm{a}$ & $132,15 \mathrm{a}$ & $126,0 \mathrm{a}$ & $25,9 \mathrm{a}$ \\
D & Tanpa Pupuk (Kontrol) & $18,3 \mathrm{c}$ & $112,30 \mathrm{~b}$ & $103,3 \mathrm{~b}$ & $20,8 \mathrm{~d}$ \\
\hline & KK $(\%)$ & 12,85 & 10,30 & 16,72 & 12,07 \\
\hline
\end{tabular}

Angka pada lajur yang diikuti oleh huruf yang sama tidak berbeda nyata pada taraf uji DNMRT 5\%. 
Tabel 3. Pengaruh Penggunaan Pupuk Terhadap Hasil Gabah Kering Panen dan Peningkatan Hasil Padi Sawah, Sungai Lareh Kecamatan Koto Tangah, Kota Padang Tahun 2009.

\begin{tabular}{clcc}
\hline No. & Perlakuan & $\begin{array}{r}\text { Hasil gabah kering } \\
\text { panen (GKP ton/ha) }\end{array}$ & $\begin{array}{c}\text { Peningkatan hasil } \\
(\%)\end{array}$ \\
\hline A & Urea+KCl & 5,04 bc & 14,03 \\
B & Urea+SP36 & $5,69 \mathrm{ab}$ & 28,73 \\
C & Urea+SP36+KCl & 6,13 a & 38,69 \\
D & Tanpa Pupuk (Kontrol) & $4,42 \quad$ d & - \\
\hline & KK $(\%)$ & 10,19 & \\
\hline
\end{tabular}

Angka pada lajur yang diikuti oleh huruf yang sama tidak berbeda nyata pada taraf uji DNMRT 5\%.

$\mathrm{SP} 36+\mathrm{KCl}(22,9 \mathrm{~cm})$, perlakuan (B) Urea + P36 $(22,5 \mathrm{~cm})$ dan berbeda nyata dengan perlakuan lainnya, malai terpendek didapat pada perlakuan (D) tanpa pupuk $(18,3 \mathrm{~cm})$. Jumlah gabah per malai berkisar 107,30 - 132,15 butir, dimana jumlah gabah per malai terbanyak didapat pada perlakuan (C) Urea $+\mathrm{SP} 36+\mathrm{KCl}$ $(132,15$ butir) dan berbeda nyata dengan perlakuan lainnya, sedangkan jumlah gabah paling sedikit didapat pada perlakuan (A) Urea $+\mathrm{KCl}(107,30 \mathrm{~cm})$. Jumlah gabah bernas per malai berkisar 91,4 - 126,0 butir, dimana jumlah malai terbanyak didapat pada perlakuan (C) $\mathrm{Urea}+\mathrm{SP} 36+\mathrm{KCl}$ (126,0 butir). Berat 1000 butir gabah tertinggi didapat pada perlakuan (C) 25,9 gr dan berbeda nyata dengan semua perlakuan lainnya, sedangkan berat gabah 1000 butir terendah didapat pada perlakuan tanpa pupuk yaitu 20,8 gr.

\section{Hasil Gabah}

Pada Tabel 3 terlihat, pengaruh penggunaan pupuk terhadap persentase peningkatan hasil dan hasil gabah kering panen menunjukkan perbedaan yang nyata. Penggunaan pupuk lengkap (C) nyata memberikan peningkatan hasil sebesar 38,69\% atau 6,13 ton/ha dibandingkan dengan tanpa menggunakan pupuk yaitu 4,42 ton/ha. Hasil gabah kering panen pada perlakuan A yang hanya menggunakan kombinasi pupuk Urea dan KCL atau perlakuan $\mathrm{B}$ yang hanya menggunakan kombinasi pupuk Urea dan SP36, memberikan hasil gabah kering panen yang cukup baik (5,054 dan 5,69 ton/ha) dibandingkan dengan tidak diberikan pupuk 4,42 ton/ha). Hal ini diduga karena hara tanah terutama $\mathrm{P}$ dan $\mathrm{K}$ cukup tersedia.

Menurut Taslim et. al. (1993), tanah sawah relatif mengandung banyak $\mathrm{P}$ dan $\mathrm{K}$ disamping penambahan $\mathrm{P}$ dan $\mathrm{K}$ melalui pengairan sehingga pemberian pupuk $\mathrm{P}$ dan $\mathrm{K}$ tidak begitu nyata berpengaruhnya. Namun pada penelitian ini jika pupuk $\mathrm{P}$ dan $\mathrm{K}$ tidak diberikan maka peningkatan hasil yang dicapai berkisar 14,03 sampai $28,73 \%$ dibandingkan tanpa pupuk. Selanjutnya, meskipun diduga $\mathrm{P}$ tanah tinggi namun bila pupuk $\mathrm{P}$ tidak diberikan maka peningkatan hasil hanya $14,03 \%$. Menurut Taher dan Zaini (1991), tanggap padi terhadap pemupukan $\mathrm{P}$ kurang berkorelasi dengan kadar $\mathrm{P}$ tanah. Bila $\mathrm{P}$ tidak diberikan maka hasil gabah yang dicapai hampir selalu lebih rendah. Menurut Partohardjono dan Makmur (1993) menyatakan bahwa hara $\mathrm{N}, \mathrm{P}$, dan $\mathrm{K}$ merupakan hara makro utama yang diperlukan tanaman padi dan sering menjadi faktor pembatas produksi.

\section{KESIMPULAN}

1. Pemberian pupuk lengkap (Urea+SP36+ $\mathrm{KCl}$ ), atau kombinanasi Urea, $\mathrm{KCl}$, atau kombinasi Urea, SP36 menunjukkan pengaruh yang nyata terhadap pertumbuhan dan hasil dibandingkan dengan tanpa pemberian pupuk.

2. Penggunaan pupuk Urea $+\mathrm{KCl}$ peningkatan hasil yang diperoleh 14,03\%, dan penggunaan pupuk Urea + SP36 peningkatan hasil yang diperoleh $28,73 \%$, sedangkan dengan menggunakan pupuk lengkap peningkatan hasil diperoleh sebesar 38,69\% atau 6,13 ton/ha gabah kering panen.

3. Untuk mendapatkan pertumbuhan dan hasil padi sawah yang optimal sebaiknya pupuk diberikan secara lengkap yaitu Urea, SP36, dan $\mathrm{KCl}$.

\section{DAFTAR PUSTAKA}

Adiningsih, S. J. dan M. Soepartini. 1995. Pengelolaan Pupuk pada Sistem Usahatani Lahan Sawah. Makalah disampaikan dalam Apresiasi Metodologi Pengkajian Usahatani Berbasis Padi dengan Wawa- 
san Agribisnis. Bogor, 7-9 September 1995. PSE, Bogor.

Balitpa. 2003. Kajian Kebutuhan Pupuk NPK pada Padi Sawah Melalui Petak Omisi di Wilayah Pengembangan PTT. Balai Penelitian Padi, Bogor.

Burbey, S. Abdullah, E. Mawardi, A. Taher, dan Imran. 2000. Teknologi P-starter Solusi Kelangkaan Pupuk Fospor. Dalam Hamzah, et. al. (Penyunting). Monograf No. 03, BPTP Sukarami Sumatera Barat, Padang.

Darwis, S. N. 1979. Agronomi Tanaman Padi. Jilid I. Teori Pertumbuhan dan Meningkatkan Hasil Padi. Lembaga Pusat Penelitian Pertanian Perwakilan Padang, Padang.

Nur, M., Marwan, H. M., dan Basri, A. B. 2003. Pengelolaan Tanaman Terpadu Nanggroe Aceh Darrussalam. Prosiding Lokakarya Pelaksanaan Program Peningkatan Produktivitas Padi Terpadu (P3T) Tahun 2002. Puslitbangtan Bogor, Bogor.

Partohardjono, S., dan A. Makmur. 1993. Peningkatan Produksi Padi. Dalam Ismunaji et al. (ed.). Padi Buku 2. Puslitbangtan, Bogor.

Sarief, E. S. 1985. Kesuburan dan Pemupukan Tanah Pertanian. Pustaka Buana, Bandung.
Setyorini, D., A. Kasno, I. G. M. Subiksa, D. Nursyamsi, Sulaeman, dan J. Sri Adiningsih. 1995. Evaluasi Status P dan K Tanah Sawah Intensifikasi Sebagai Dasar Penyusunan Rekomendasi Pemupukan $\mathrm{P}$ dan $\mathrm{K}$ di Sumatera Barat, Sumatera Selatan, dan Kalimantan Selatan. Pembahasan Laporan Paket Teknologi Hasil Penelitian ARMP-I, Cisarua, Bogor.

Taher, A. dan Z. Zaini. 1991. Prospek Penambangan $P$ Tanah Sawah dalam Upaya Peningkatan Efisiensi Pemupukan $P$ dan Optimasi Usahatani. Makalah Disampaikan dalam Penyiapan Review TSP di Puslitbangtan Bogor, Bogor.

Taslim, H., S. Partohardjono, dan Subandi. 1993. Pemupukan Padi Sawah. Dalam Buku Padi 2. Badan Litbang Pertanian. Puslitbangtan Bogor, Bogor. 